\title{
Pengaruh Pembelajaran Kooperatif Model STAD Terhadap Keaktifan dan Hasil Belajar IPA Kelas VII SMP
}

\author{
Ni Putu Idayani
}

SMP Negeri 3 Kubu, Karangasem, Indonesia

\author{
A R T I C L E I N F O \\ Article history: \\ Received 19 \\ November 2017 \\ Received in revised \\ form \\ 6 Januari 2018 \\ Accepted 12 Januari \\ 2018 \\ Available online 20 \\ Februari 2018 \\ Kata Kunci: \\ STAD, keaktifan \\ belajar, hasil belajar \\ Keywords: \\ STAD, learning \\ activeness, learning \\ outcomes
}

A B S T R A K

Penelitian ini dilatarbelakangi oleh kurang aktif dan rendahnya hasil belajar IPA siswa. Penelitian ini bertujuan untuk meningkatkan keaktifan dan hasil belajar IPA siswa melalui penerapan pembelajaran kooperatif model STAD dalam aktivitas pembelajaran. Data dalam penelitian ini dikumpulkan dengan metode observasi yang dilengkapi dengan pedoman observasi terhadap keaktifan belajar siswa dan metode tes yang dilengkapi dengan instrumen berupa tes (soal) objektif. Data yang terkumpul dianalisis secara kualitatif dan menggunakan rumus statistik. Hasil pelaksanaan tindakan pada penelitian ini menunjukkan bahwa (1) Penerapan model pembelajaran kooperatif model STAD dapat meningkatkan keaktifan siswa. Pada refleksi awal keaktifan belajar siswa sebesar 4,87 yang tergolong kurang aktif. Pada siklus I rata-rata keaktifan belajar siswa adalah 6,27 yang tergolong cukup aktif; sedangkan pada siklus II rata-rata keaktifan belajar siswa adalah 7,57 yang tergolong aktif. (2) Penerapan model pembelajaran kooperatif model STAD dapat meningkatkan hasil belajar IPA siswa . Pada refleksi awal nilai ratat-rata siswa sebesar 58,83. Hasil evaluasi pada siklus I menunjukkan bahwa nilai rata-rata siswa sebesar 67,67, pada siklus II nilai rata-rata siswa sebesar 79,52. Dari hasil tersebut ada perbedaan keaktifan dan hasil belajar siswa antara sebelum dan sesudah penerapan pembelajaran kooferatif model STAD. Dengan demikian penerapan pembelajaran kooferatif model STAD dapat meningkatkan keaktifan dan hasil belajar IPA.

A B S T R A C T

This research was motivated by students' less active and low learning outcomes in Science. This study aims to improve the students activity and learning outcomes in science through the application of cooperative learning STAD model in learning activities. The data in this research were collected by observation method which was accompanied by observation guidance on student learning activity and test method which was completed with instrument in the form of objective test. The collected data were analyzed qualitatively and using statistical formula. The results of action implementation in this study indicate that (1) Application of cooperative learning model STAD model can improve students activeness. On the initial reflection, the students learning activities showed 4.87 which was classified as less active. In cycle I the average of students' learning activity was 6.27 which is quite active; whereas in cycle II the average of students' learning activeness was 7.57 which was classified as active. (2) The application of cooperative learning model STAD model can improve students' learning outcomes of Science. On the initial reflection, the students' average score was 58.83. The results of evaluation in cycle I showed that the average score of students was 67.67 , in the second cycle the average score of students was 79.52. From these results, there were differences in activeness and students' learning outcomes between before and after the application of the STAD cooperative learning model. Thus the application of the cooperative learning STAD model can improve the activeness and the learning result of Science. 


\section{Pendahuluan}

Pada hakekatnya pendidikan adalah suatu usaha penyiapan subjek didik untuk menghadapi lingkungan hidup yang selalu mengalami perubahan yang semakin pesat. Pendidikan juga merupakan kiat dalam menerapkan prinsip-prinsip ilmu pengetahuan dan teknologi bagi pembentukan manusia seutuhnya. Hal ini sejalan dengan tujuan pendidikan nsional yang tertuang dalam Undang-Undang No.20 Tahun 2003 (Sisdiknas,pasal 3) yakni berkembangnya potensi peserta didik agar menjadi manusia yang beriman dan bertaqwa kepada Tuhan Yang Maha Esa, berakhlak mulia, sehat, berilmu, cakap, kreatif, mandiri, dan menjadi warga negara yang demokratis serta bertanggung jawab. Pendidikan merupakan cerminan kemajuan suatu bangsa. Semakin tinggi budaya suatu bangsa, semakin tinggi pula tingkat pendidikan bangsa tersebut. Bangsa yang besar adalah bangsa yang memperhatikan pendidikan warga negaranya (Utami, 2015). Dengan demikian melalui pendidikan diharapkan dapat meningkatkan kualitas kehidupan pribadi maupun masyarakat, serta mampu menghasilkan sumber daya manusia yang berkualitas dan professional.

Sebagai tolak ukur keberhasilan Pendidikan Nasional adalah dengan melihat prestasi belajar siswa serta nilai kelulusan yang diperoleh siswa selama mereka menimba ilmu di bangku sekolah. Perkembangan di bidang ilmu pengetahuan dan teknologi serta dalam menyiapkan sumber daya manusia yang berkualitas, untuk mencerdaskan kehidupan bangsa Indonesia melalui pendidikan (Sunilawati, 2013). Prestasi siswa menunjukkan tingkat pemahaman mereka terhadap materi pelajaran yang mencakup ranah kognitif, afektif, dan psikomotor. Kemampuan siswa memahami materi pelajaran terutama bagi siswa sekolah dasar sangat dipengaruhi oleh kemampuan dasar yang dimiliki dan proses pembelajaran di kelas.

Pembelajaran adalah proses interaksi peserta didik dengan guru dan sumber belajar pada suatu lingkungan belajar. Proses pembelajaran perlu direncanakan, dilaksanakan, dinilai, dan diawasi agar dapat terlaksana secara efektif dan efesien. Pembelajaran yang baik adalah bersifat menyeluruh dalam melaksanakannya dan mencakup berbagai aspek, baik aspek kognitif, afektif, maupun psiomotorik, sehingga dalam pengukuran tingkat keberhasilannya selain dilihat dari segi kuantitas juga dari kualitas yang telah dilakukan di sekolah-sekolah (Sulasti, 2013). Peserta didik harus berperan besar dalam pembelajaran sehingga pembelajaran tidak hanya berpusat pada guru, peran guru sangatlah penting untuk menciptakan suasana yang kondusif dalam pembelajaran berlangsung (Dwipayana, 2017). Guru sebagai pendidik harus mampu membantu siswa untuk menumbuhkan kelima kemampuan tersebut dengan menempatkan siswa sebagai pembelajar yang aktif dengan memberikan pembelajaran yang bermakna dan proses pembelajaran yang dirancang sedemikian rupa agar tujuan pembelajaran yang diinginkan bisa tercapai (Dewi, 2016). Selain itu untuk meningkatkan minat siswa dalam pembelajaran, guru harus dapat memilih dan menggunakan metode pembelajaran yang tepat dan efektif (Parmiti, 2017). Mengingat kebhinekaan budaya, keragaman latar belakang dan karakteristik peserta didik, serta tuntutan untuk menghasilkan lulusan yang bermutu; proses pembelajaran untuk setiap mata pelajaran harus fleksibel, bervariasi, dan memenuhi standar. Proses pembelajaran pada setiap satuan pendidikan dasar dan menengah harus interaktif, inspiratif, menyenangkan, menantang, dan memotivasi peserta didik (Sanjaya, 2006:27). Hal tersebut bertujuan agar peserta didik aktif, kreatif, dan mandiri sesuai dengan bakat, minat, dan perkembangan fisik, serta psikologis masing-masing peserta didik, sesuai dengan tujuan yang tercantum dalam Kurikulum Tingkat Satuan Pendidikan (Tim BSNP, 2006:4)

Sesuai dengan amanat Peraturan Pemerintah Nomor 19 Tahun 2005 tentang Standar Nasional Pendidikan yang dikemukakan dalam Darma (2006:3), salah satu standar yang harus dikembangkan adalah standar proses. Standar proses adalah standar nasional pendidikan yang berkaitan dengan pelaksanaan pembelajaran pada satuan pendidikan untuk mencapai kompetensi lulusan. Standar proses tersebut sangat menentukan dalam pelaksanaan proses pembelajaran yang dilaksanakan oleh guru dan siswa di dalam kelas. Hal tersebut akan tampak pada kegiatan inti pembelajaran. Pelaksanaan kegiatan inti merupakan proses pembelajaran untuk mencapai kompetensi dasar yang dilakukan secara interaktif, inspiratif, menyenangkan, menantang, memotivasi peserta didik untuk berpartisipasi secara aktif dalam kegiatan pembelajaran. Namun yang terlihat dilapangan dalam pembelajaran selama ini KBM yang dilaksanakan masih menggunakan madia dan metode yang kurang menarik siswa. Sehingga kesan yang tersimpan dalam memori anak mudah hilang (Asriyah, 2014). Dengan demikian, Pelaksanaan pembelajaran di sekolah sebaiknya berorientasi pada model dan tujuan pembelajaran tersebut, yaitu mengembangkan kemampuan akademik dan interaksi sosial dengan meningkatkan keaktifan peserta didik dalam pembelajaran (Susanto, 2012). Selain itu hal yang tak kalah penting adalah pemilihan metode pembelajaran yang dilakukan oleh guru pun seharusnya juga metode yang menuntut agar siswa terlibat secara aktif dalam kegiatan pembelajaran di kelas. 
Ilmu pengetahuan alam (IPA) merupakan salah satu mata pelajaran yang turut berperan penting dalam pendidikan wawasan, keterampilan, dan sikap ilmiah. Melalui pembelajaran dan pengembangan potensi diri pada pembelajaran IPA siswa akan memperoleh bekal pengetahuan, keterampilan, dan sikap yang diperlukan untuk memahami dan menyesuaikan diri terhadap fenomena dan perubahan-perubahan di lingkungan sekitar, disamping memenuhi keperluan untuk jenjang melanjutkan pendidikan ke jenjang yang lebih tinggi. IPA mengandung tiga dimensi utama, yaitu dimensi produk, proses, dan sikap ilmiah. Dimensi produk IPA berupa fakta, konsep, prinsip, hukum, dan teori IPA. Dimensi proses, maksudnya adalah bagaimana proses mendapatkan IPA. IPA diperoleh melalui penelitian dengan menggunakan langkah-langkah tertentu yang disebut metode ilmiah (Juniati, 2017).

Pembelajaran IPA di SMP Negeri 3 Kubu merupakan wahana untuk membekali siswa dengan pengetahuan, keterampilan, dan sikap yang diperlukan untuk melanjutkan pendidikan dan untuk menyesuaikan diri dengan perubahan-perubahan disekelilingnya. Dilihat dari kondisi pembelajaran, melalui hasil observasi awal dilakukan di SMP Negeri 3 Kubu keaktifan belajar siswa dalam pembelajaran kurang aktif dan hasil belajar IPA siswa secara klasikal juga masih rendah. Data yang diperoleh dari observasi awal yaitu secara klasikal rata-rata keaktifan belajar siswa 4,87. Angka atau hasil tersebut berada pada kategori kurang aktif. Sedangkan nilai rata-rata siswa diperoleh 58,83, nilai rata-rata tersebut tergolong rendah. Ketuntasan klasikal belajar adalah 43,33\%, hasil tersebut menunjukkan bahwa secara klasikal siswa kelas VIID SMP N 3 Kubu belum memenuhi persentase KKM yang ditargetkan yaitu secara klasikal minimal $85 \%$ siswa tuntas. Hal ini disebabkan karena mayoritas guru dalam proses pembelajaran menggunakan metode ceramah. Guru lebih banyak mendominasi pembelajaran sehingga hanya terjadi interaksi satu arah yaitu interaksi dari guru ke siswa, sedangkan yang diharapkan dalam pembelajaran adanya interaksi dari guru ke siswa, dari siswa ke guru, dan dari siswa ke siswa. Kurangnya pemahaman guru mengenai teknik-teknik pembelajaran terbaru yang dapat diterapkan dalam proses pembelajaran menyebabkan masih banyak guru menggunakan metode ceramah dalam pembelajaran, sehingga sampai saat ini pembelajaran masih didominasi oleh guru.

Pembelajaran dengan metode ceramah menyebabkan siswa dalam mengikuti pembelajaran hanya terpaku dengan apa yang diberikan guru dalam pembelajaran. Siswa hanya mendengarkan tanpa melakukan aktivitas pada saat pembelajaran berlangsung, tidak adanya motivasi siswa untuk mengikuti pembelajaran, hal inilah yang menyebabkan siswa bosan mengikuti pembelajaran sehingga hasil belajar IPA rendah. Dalam proses pembelajaran keaktifan belajar siswa kurang dimana keaktifanbelajar siswa sangat penting untuk mengetahui sejauh mana siswa berperan aktif dalam mengikuti pembelajaran.

Berdasarkan uraian di atas, salah satu alternatif yang dapat ditempuh untuk mengatasi permasalahan tersebut adalah dengan cara melaksanakan pembelajaran yang inovatif pada mata pelajaran IPA. Salah satu pembelajaran inovatif yang dapat diterapkan sesuai dengan masalah yang dihadapi siswa adalah penerapan pembelajaran kooperatif model STAD ( Student Team Achievement Division).

Menurut Ibrahim, dkk. (2000:7), model pembelajaran kooperatif dikembangkan untuk mencapai setidaknya tiga tujuan pembelajaran, yakni (a) meningkatkan hasil belajar akademik, (b) menerima perbedaan individu, dan (c) mengembangkan keterampilan sosial. Pembelajaran model STAD merupakan salah satu model pembelajaran kooperatif yang menuntut siswa untuk berperan aktif sehingga siswa harus benar-benar mempersiapkan diri sebelum proses pembelajaran dilaksanakan.

Pembelajaran kooperatif model STAD yang dilaksanakan dalam bentuk kelompok, dimana berlangsung suatu diskusi atau pemecahan masalah bersama. Model pembelajaran STAD akan memberikan manfaat kepada siswa seperti, ( 1 )meningkatkan motivasi belajar siswa, ( 2 ) memperluas perspektif intelektual siswa, ( 3 ) merangsang kemampuan berpikir siswa, (4) menyempurnakan dan meluruskan nilai-nilai dan pandangan siswa, (5) membentuk siswa untuk tidak menjadi egosentris.

Menurut Anton M. Mulyono (2001 : 26), Aktivitas artinya "kegiatan atau keaktifan". Jadi segala sesuatu yang dilakukan atau kegiatan-kegiatan yang terjadi baik fisik maupun non-fisik, merupakan suatu aktifitas. Sementara itu, menurut Sriyono aktivitas adalah segala kegiatan yang dilaksanakan baik secara jasmani atau rohani. Aktivitas siswa selama proses belajar mengajar merupakan salah satu indikator adanya keinginan siswa untuk belajar.

Kemudian, Oemar Hamalik (2001: 28), menyatakan bahwa belajar adalah "Suatu proses perubahan tingkah laku individu melalui interaksi dengan lingkungan". Aspek tingkah laku tersebut adalah: pengetahuan, pengertian, kebiasaan, keterampilan, apresiasi, emosional, hubungan sosial, jasmani, etis atau budi pekerti dan sikap. Sedangkan, Sardiman A.M. (2003 : 22) menyatakan: "Belajar merupakan suatu proses interaksi antara diri manusia dengan lingkungannya yang mungkin berwujud pribadi, fakta, konsep ataupun teori".

Berdasarkan beberapa pendapat di atas, dapat disimpulkan bahwa aktivitas belajar merupakan segala kegiatan yang dilakukan dalam proses interaksi (guru dan siswa) dalam rangka mencapai tujuan 
belajar. Aktivitas yang dimaksudkan di sini penekanannya adalah pada siswa, sebab dengan adanya aktivitas siswa dalam proses pembelajaran terciptalah situasi belajar aktif, seperti yang dikemukakan oleh Rochman Natawijaya dalam Depdiknas (2005 : 31), belajar aktif adalah "Suatu sistem belajar mengajar yang menekankan keaktifan siswa secara fisik, mental intelektual dan emosional guna memperoleh hasil belajar berupa perpaduan antara aspek koqnitif, afektif dan psikomotor".

Keaktifan siswa selama proses belajar mengajar merupakan salah satu indikator adanya keinginan atau motivasi siswa untuk belajar. Siswa dikatakan memiliki keaktifan apabila ditemukan ciri-ciri perilaku seperti : sering bertanya kepada guru atau siswa lain, mau mengerjakan tugas yang diberikan guru, mampu menjawab pertanyaan, senang diberi tugas belajar, dan lain sebagainya. Seorang pakar pendidikan, Trinandita (1984) menyatakan bahwa" hal yang paling mendasar yang dituntut dalam proses pembelajaran adalah keaktifan siswa". Keaktifan siswa dalam proses pembelajaran akan menyebabkan interaksi yang tinggi antara guru dengan siswa ataupun dengan siswa itu sendiri. Hal ini akan mengakibatkan suasana kelas menjadi segar dan kondusif, dimana masing - masing siswa dapat melibatkan kemampuannya semaksimal mungkin. Aktivitas yang timbul dari siswa akan mengakibatkan pula terbentuknya pengetahuan dan keterampilan yang akan mengarah pada peningkatan prestasi.

Menurut Dimyati dan Mudjiono (2006:3), hasil belajar merupakan hasil dari suatu interaksi tindak belajar dan tindak mengajar. Dari sisi guru, tindakan mengajar diakhiri dengan proses evaluasi hasil belajar, dari sisi siswa hasil belajar merupakan puncak proses belajar. Kemampuan siswa dalam menyerap atau memahami suatu bahan yang telah diajarkan dapat diketahui berdasarkan penilaian yang dilakukan oleh guru. Salah satu upaya mengukur hasil belajar siswa dilihat dari hasil belajar siswa itu sendiri. Bukti dari usaha yang dilakukan dalam proses belajar adalah hasil belajar yang diukur melalui tes. Hal ini sesuai dengan yang dikemukakan oleh Ahmadi (1984:35) dalam Dimyati dan Mudjiono (2006:4) bahwa "Hasil belajar adalah hasil yang dicapai dalam suatu usaha, dalam hal ini usaha belajar dalam perwujudan prestasi belajar siswa yang dilihat pada setiap mengikuti tes". Hasil belajar dalam penelitian ini diperoleh melalui tes yang diberikan pada setiap akhir siklus.

Adapun tujuan penelitian ini adalah sebagai berikut. (1) Untuk mengetahui keaktifan belajar siswa kelas VII dalam pembelajaran IPA setelah diterapkan pembelajaran kooperatif model STAD. (2) Untuk meningkatkan hasil belajar IPA siswa kelas VII melalui penerapan pembelajaran kooperatif model STAD.

\section{Metode}

Penelitian ini menggunakan rancangan penelitian tindakan kelas yang dilakukan dengan beberapa siklus sampai memperoleh hasil yang diharapkan (wardani, 2003). Siklus yang digunakan dalam penelitian ini adalah sebagai berikut.

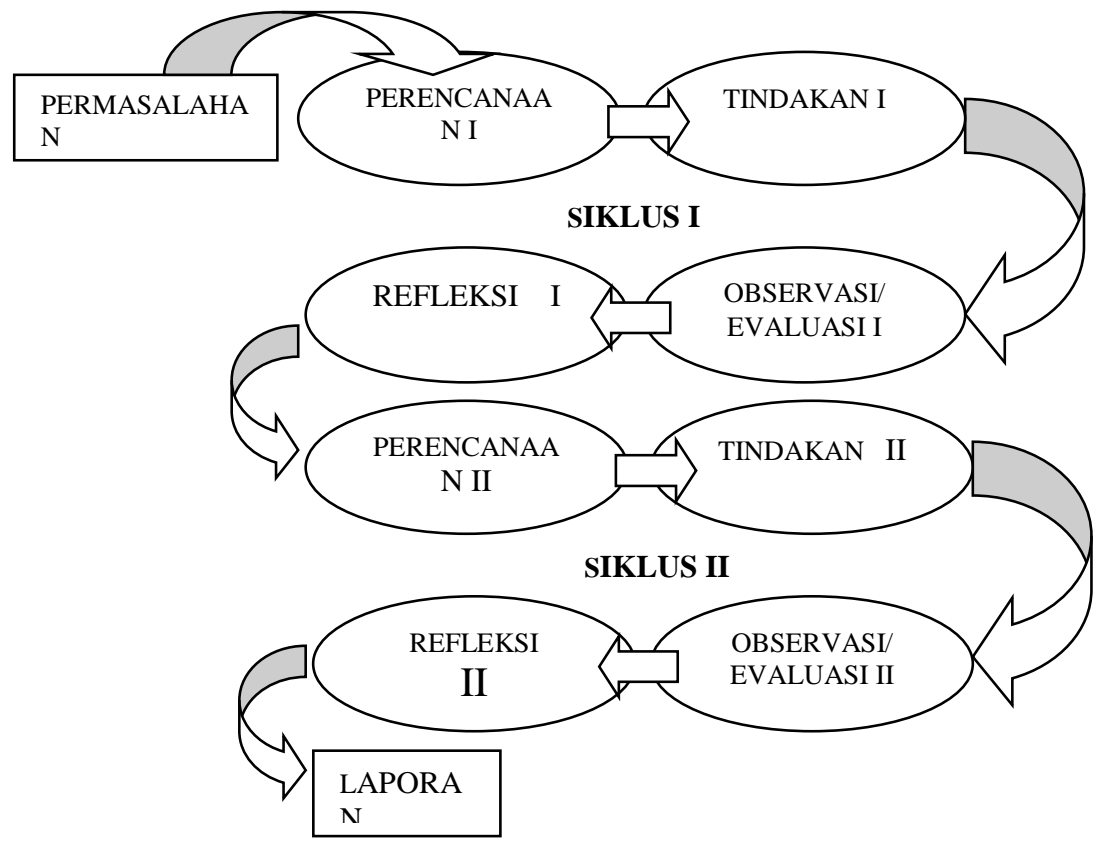

Bagan.01 Siklus Penelitian Tindakan Kelas (Suyanto, dkk., 1997: 21)

Populasi dalam penelitian ini adalah siswa kelas VII SMP Negeri 3 Kubu. Subjek dalam penelitian ini adalah siswa kelas VIID SMP Negeri 3 Kubu, yang berjumlah 30 orang siswa. Siswa tersebut dipilih sebagai subjek penelitian karena hasil belajar IPA siswa rata-rata belum memenuhi standar ketuntasan 
atau kriteria ketuntasan minimal (KKM) yakni 66, sedangkan nilai yang diperoleh siswa adalah rata-rata 58,83. Sementara itu, objek dalam penelitian ini adalah keaktifan dan hasil belajar IPA siswa kelas VIID SMP Negeri 3 Kubu. Variabel penelitian terdiri dari variabel bebas dan variabel terikat. Variabel bebas yaitu model pembelajaran kooperatif model STAD. Variabel terikat yaitu keaktifan dan hasil belajar.

Prosedur penelitian yang dilakukan meliputi (1) refleksi awal, peneliti mengkaji masalah-masalah yang dihadapi oleh siswa kelas VII dalam pembelajaran IPA; (2) rencana tindakan; (3) Pelaksanaan tindakan; (4) Observasi, pada kegiatan ini peneliti berpedoman pada pedoman observasi yang telah dilakukan; (5) Evaluasi untuk mengetahui keberhasilan siswa dalam pembelajaran IPA dengan cara memberikan tes objektif yang terdiri dari 20 butir soal; (6) Refleksi dilaksanakan setelah tindakan usai.

Pengumpulan data dilakukan dengan cara observasi dan tes. Observasi merupakan usaha sadar yang digunakan untuk mengumpulkan data yang dilakukan secara sistematis dengan prosedur tertentu ( Arikunto, 1996:177). Metode observasi ini digunakan untuk mengumpulkan data keaktifan belajar siswa di kelas. Kegiatan observasi yang dilakukan ini dilengkapi intrumen pengumpulan data, yakni berupa pedoman observasi siswa. Tes digunakan untuk mengukur hasil pencapaian belajar siswa. Tes merupakan alat ukur yang penting dalam penelitian pendidikan. Nilai yang diperoleh dapat dijadikan petunjuk mengenai taraf kemampuan yang diukur (Djojosuroto, 2004:59). Jenis tes yang diberikan adalah tes objektif dan diberikan dalam bentuk tes tulis.

Data keaktifan belajar siswa diperoleh melalui rumus konversi keaktifan berikut.

Tabel 1. Rumus Konversi Keaktifan Belajar Siswa

\begin{tabular}{ccc}
\hline No & Kriteria kualitas & Kategori \\
\hline 1 & $\mathrm{x} \geq \mathrm{Mi}+1,5 \mathrm{Sdi}$ & Sangat Aktif \\
2 & $\mathrm{Mi}+0,5 \mathrm{SDi} \leq \mathrm{x}<\mathrm{Mi}+1,5 \mathrm{Sdi}$ & Aktif \\
3 & $\mathrm{Mi}-0,5 \mathrm{SDi} \leq \mathrm{x}<\mathrm{Mi}+0,5 \mathrm{Sdi}$ & Cukup Aktif \\
4 & $\mathrm{Mi}-1,5 \mathrm{SDi} \leq \mathrm{x}<\mathrm{Mi}-0,5 \mathrm{Sdi}$ & Kurang Aktif \\
5 & $\mathrm{x}<\mathrm{Mi}-1,5 \mathrm{Sdi}$ & Sangat Kurang Aktif \\
\hline
\end{tabular}

Tabel 2. Konversi Skor Keaktifan Belajar Siswa

\begin{tabular}{cc}
\hline Skor & Kategori \\
\hline $\mathrm{x} \geq 9$ & Sangat Aktif \\
$7 \leq x<9$ & Aktif \\
$5 \leq x<7$ & Cukup Aktif \\
$3 \leq x<5$ & Kurang Aktif \\
$\mathrm{x}<3$ & Sangat Kurang Aktif \\
\hline
\end{tabular}

Dalam penilaian hasil belajar digunakan nilai dengan skala $0-10$. Jika siswa menjawab seluruh soal dengan benar, siswa akan memeroleh nilai 10. Jika siswa menjawab seluruh soal salah, nilai yang diperoleh adalah nol (0). Skala nilai yang digunakan untuk mengukur hasil belajar didasarkan pada norma absolut. Norma absolut secara umum disebut dengan penilaian acuan patokan (PAP). Nurkancana dan Sunartana (1986:78) menyatakan bahwa "Norma absolut merupakan suatu norma yang ditetapkan secara absolut (mutlak) oleh guru atau pembuat tes, berdasarkan atas jumlah soal, bobot masing-masing soal serta persentase penguasaan yang dipersyaratkan". Dalam mengolah skor mentah menjadi skor standar digunakan skala sebelas. Skala sebelas adalah suatu susunan tingkatan yang terdiri atas sebelas kategori. Masing-masing kategori dinyatakan dengan angka dari 0 sampai dengan 10. Angka 0 (nol) menyatakan kategori terendah dang angka 10 menyatakan kategori tertinggi.

Berdasarkan pedoman penilaian di atas, secara individu siswa dikatakan tuntas dalam menguasai materi apabila nilai yang diperoleh minimal 66 (sesuai dengan Kriteria Ketuntasan Minimal). Secara klasikal, pembelajaran dikatakan tuntas apabila minimal 85\% dari jumlah siswa yang ada di kelas itu memperoleh nilai minimal 66, sehingga tindakan bisa dihentikan. Sebaliknya, jika jumlah siswa yang memperoleh nilai 66 kurang dari 85\%, tindakan perlu diulang sampai diperoleh nilai yang diharapkan. Rumus untuk mengetahui persentase siswa yang sudah mencapai ketuntasan belajar (KB) adalah dengan cara membagi jumlah siswa yang memeroleh nilai 66 ke atas dengan jumlah seluruh siswa, kemudian dikalikan $100 \%$. Data yang dianalisis berdasarkan data hasil observasi dan hasil tes disajikan dalam tabel dan dipaparkan secara deskriptif kualitatif. Teknik deskriptif kualitatif merupakan teknik penyajian data dengan menggunakan kata-kata atau secara naratif verbal. Kriteria keberhasilan ditunjukkan dengan adanya perubahan keaktifan belajar yang dialami oleh siswa. Kriteria keberhasilan siswa dalam proses 
belajar mengajar ditunjukkan dengan presentase, yaitu minimal 85\% dari jumlah keseluruhan siswa memperoleh nilai minimal 66. Konversi hasil belajar dan keaktifan siswa dapat dilihat pada tabel berikut.

Tabel 3. Konversi Nilai dan Kategori Hasil Belajar

\begin{tabular}{cc}
\hline RENTANG NILAI & HASIL BELAJAR \\
\hline $85-100$ & Sangat Baik \\
$70-84$ & Baik \\
$60-69$ & Cukup \\
$45-59$ & Rendah \\
$0-44$ & Sangat Rendah \\
\hline
\end{tabular}

Agung (1999:45)

\section{Hasil dan Pembahasan}

Tabel 4. Hasil Observasi Terhadap Keaktifan Belajar Siswa Pada Refleksi Awal, Siklus I, dan Siklus II

\begin{tabular}{ccccccc}
\hline \multirow{2}{*}{ Kategori } & \multicolumn{3}{c}{ Jumlah Siswa } & \multicolumn{3}{c}{ Persentase } \\
\cline { 2 - 6 } & $\begin{array}{c}\text { Refleks } \\
\text { i awal }\end{array}$ & Siklus I & $\begin{array}{c}\text { Siklus } \\
\text { II }\end{array}$ & $\begin{array}{c}\text { Refleksi } \\
\text { awal }\end{array}$ & Siklus I & Siklus II \\
\hline Sangat aktif & - & - & 3 & - & - & $10 \%$ \\
Aktif & 6 & 8 & 22 & $20,00 \%$ & $26,67 \%$ & $73,33 \%$ \\
Cukup aktif & 9 & 21 & 5 & $30,00 \%$ & $70,00 \%$ & $16,67 \%$ \\
Kurang aktif & 13 & 1 & - & $43,33 \%$ & $3,33 \%$ & - \\
$\begin{array}{c}\text { Sangat kurang } \\
\text { aktif }\end{array}$ & 2 & - & - & $6,67 \%$ & - & - \\
\hline
\end{tabular}

Berdasarkan tabel tersebut, dapat diketahui bahwa pada refleksi awal dari 30 orang siswa kelas VIID SMP Negeri 3 Kubu, sejumlah 2 orang (6,67\%) sangat kurang aktif, 13 orang (43,33\%) kurang aktif, 9 orang $(30,00 \%)$ cukup aktif dan 6 orang $(20,00 \%)$ aktif dalam pembelajaran IPA. Sementara itu, jika dilihat secara klasikal berdasarkan hasil penghitungan rata-rata keaktifan belajar siswa, diperoleh hasil 4,87. Angka atau hasil tersebut berada pada kategori kurang aktif. Pada siklus I dari 30 orang siswa kelas VIID SMP Negeri 3 Kubu, sejumlah 8 orang (26,67\%) aktif, 21 orang (70,00\%) cukup aktif, dan 1 orang $(3,33 \%)$ kurang aktif dalam pembelajaran IPA. Sementara itu, jika dilihat secara klasikal berdasarkan hasil penghitungan rata-rata keaktifan belajar siswa, diperoleh hasil 6,27. Angka atau hasil tersebut berada pada kategori cukup aktif. Pada siklus II dari 30 orang siswa kelas VIID SMP Negeri 3 Kubu, sejumlah 3 orang $(10,00 \%)$ sangat aktif, 22 orang $(73,33 \%)$ aktif, dan 5 orang $(16,67 \%)$ cukup aktif dalam pembelajaran IPA. Sementara itu, jika dilihat secara klasikal berdasarkan hasil penghitungan rata-rata keaktifan belajar siswa, diperoleh hasil 7,57. Angka atau hasil tersebut berada pada kategori aktif. Berdasarkan uraian tersebut, dapat diperoleh gambaran keaktifan belajar siswa pada observasi awal, siklus I, dan siklus II pada grafik berikut.



Grafik 01. Perbandingan Keaktifan Belajar Siswa 
Tabel 5. Hasil Belajar Siswa Pada Refleksi Awal, Siklus I, dan Siklus II

\begin{tabular}{lll}
\hline Tindakan & Nilai rata-rata & Ketuntasan belajar \\
\hline Observasi awal & 58,83 & $43,33 \%$ \\
\hline Siklus I & 67,67 & $66,67 \%$ \\
\hline Siklus II & 79,50 & $90,00 \%$ \\
\hline
\end{tabular}

Kriteria Ketuntasan Minimal (KKM) pada mata pelajaran IPA adalah 66, sedangkan ketuntasan klasikal belajar pada observasi awal adalah $43,33 \%$ dan pada siklus I 66,67\% dari jumlah siswa kelas VIID SMP Negeri 3 Kubu yakni memperoleh nilai 66 ke atas. Oleh karena itu, hasil observasi tersebut menunjukkan bahwa secara klasikal siswa kelas VIID SMP Negeri 3 Kubu belum memenuhi KKM yang ditargetkan dan belum pula memenuhi persentase ketuntasan klasikal yang ditargetkan. Pada siklus II nilai rata-rata tergolong baik dan ketuntasan belajar 90,00\% dari jumlah siswa kelas VIID SMP Negeri 3 Kubu. Ketuntasan belajar pada siklus II menunjukkan bahwa secara klasikal sudah memenuhi KKM yang ditargetkan. Secara lebih lengkap perbandingan hasil belajar siswa pada observasi awal, siklus I, dan siklus II dapat dilihat pada tabel berikut.
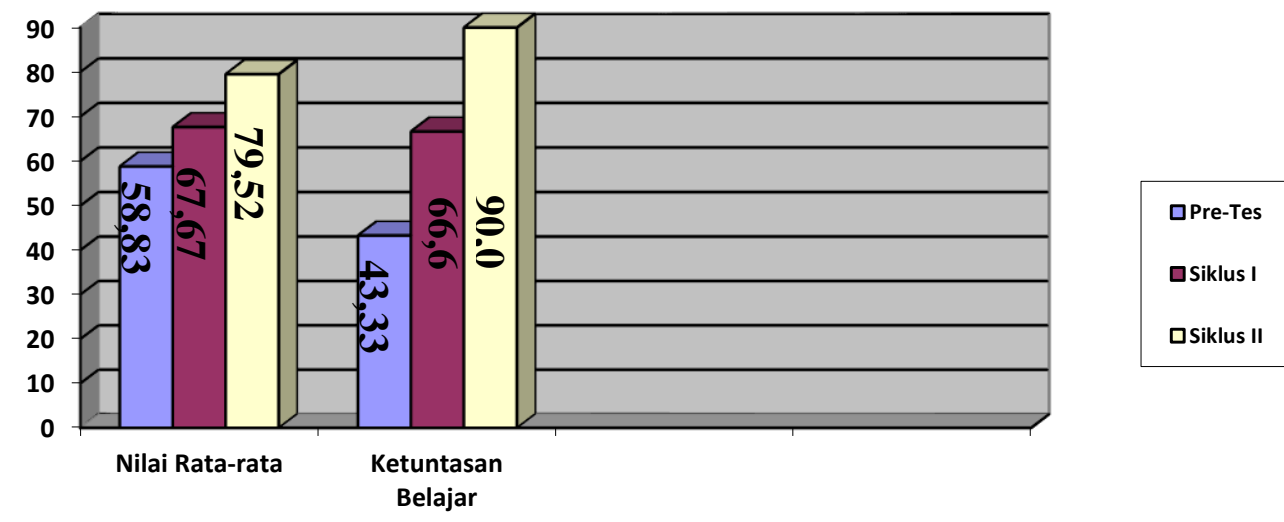

Pembahasan

Pada siklus I dan siklus II, siswa kelas VIID SMP Negeri 3 Kubu keaktifan belajarnya meningkat dalam pembelajaran IPA dari cukup aktif menjadi aktif, dilihat dari hasil perhitungan rata-ratanya menunjukkan angka yang berbeda antara rata-rata keaktifan pada siklus I dan rata-rata keaktifan pada siklus II. Pada siklus I, rata-rata keaktifan belajar siswa adalah 6,27 sedangkan pada siklus II rata-rata keaktifan belajar siswa adalah 7,57. Hal itu menunjukkan bahwa terjadi peningkatan keaktifan belajar siswa dari siklus I ke siklus II sebesar 1,30. Peningkatan ini disebabkan oleh adanya diskusi kelompok, dimana siswa termotivasi untuk beraktivitas dan berinteraksi untuk menguasai materi pelajaran.

Penerapan pembelajaran kooperatif model STAD dapat meningkatkan hasil belajar IPA siswa kelas VIID SMP Negeri 3 Kubu. Hal itu dapat diketahui melalui hasil evaluasi pada siklus I dan siklus II. Hasil evaluasi pada siklus I menunjukkan bahwa nilai rata-rata siswa kelas VIID SMP Negeri 3 Kubu pada pembelajaran IPA adalah 67,67; sedangkan hasil evaluasi pada siklus II menunjukkan bahwa nilai ratarata siswa kelas VIID SMP Negeri $3 \mathrm{Kubu}$ pada pembelajaran IPA adalah 79,50. Oleh karena itu, terjadi peningkatan sebesar 11,83. Sementara itu, jika dilihat dari ketuntasan klasikal belajar siswa kelas VIID SMP Negeri 3 Kubu juga mengalami peningkatan dari siklus I ke siklus II. Ketuntasan klasikal belajar siswa kelas VIID SMP Negeri 3 Kubu pada siklus I adalah 66,67\%. Sementara itu, pada siklus II ketuntasan klasikal belajar siswa kelas VIID SMP Negeri 3 Kubu adalah 90,00\%. Hal itu menunjukkan bahwa terjadi peningkatan ketuntasan klasikal belajar siswa dari siklus I ke siklus II sebesar 23,33\%.

Peningkatan nilai rata-rata dan ketuntasan klasikal belajar siswa tersebut terjadi karena pelaksanaan tindakan pada siklus II lebih dioptimalkan melalui berbagai upaya untuk memaksimalkan model pembelajaran STAD agar dapat meningkatkan hasil belajra siswa. Diskusi pada kelompok menyebabkan aktivitas dan interaksi diantara siswa untuk saling memotivasi dan saling membantu dalam menguasai materi pelajaran sehingga siswa yang lambat berpikir dapat dibantu dalam memahami materi pelajaran atau menambah ilmu pengetahuan. Di samping hal tersebut, pemberian umpan balik dan penghargaan juga berdampak positif terhadap hasil belajar siswa kelas VIID SMP Negeri 3 Kubu. Melalui pemberian umpan balik tersebut, siswa dapat memantapkan pemahamannya terhadap materi yang dipelajari bersama kelompok kooperatif. Pemberian penghargaan dapat memotivasi siswa untuk 
mencapai hasil belajar yang lebih tinggi. Pembelajaran akan lebih menyenangkan jika menggunakan model kooperatif tipe STAD (Permana, 2014).

Penelitian ini juga dikuatkan oleh peneliti sebelumnya, diantaranya sebelumnya, diantarnya adalah (1) Harmoko (2013) menemukan, Pengaruh Model Pembelajaran Kooperatif Tipe STAD ditinjau dari keaktifan siswa dan hasil belajar siswa mata pelajaran menggunakan alat ukur kelas jurusan teknik pemesinan di SMK Muhammadiyah prambanan, (2) Riskitri Wigih Sayekti (2014) menemukan, pengaruh model pembelajaran kooperatif tipe STAD terhadap hasil belajar matematika kelas 5 SD Negeri X jatiasih. Selain itu pini juga didukung oleh penelitian yang dilakukan oleh Sudana (2017) hasil penelitian menunjukkan bahwa penerapan model pembelajaran Tipe STAD dapat meningatkan hasil belajar IPA siswa kelas IV A semester ganjil Tahun Pelajaran 2016/2017 di SD No. 3 Dalung.

\section{Simpulan dan Saran}

Adapun simpulan dari penelitian ini adalah sebagai berikut. Pertama, penerapan pembelajaran kooperatif model STAD dapat meningkatkan keaktifan siswa kelas VIID SMP Negeri 3 Kubu dalam pembelajaran IPA. Pada observasi awal, hasil observasi terhadap keaktifan belajar siswa menunjukkan hasil 4,87 yang tergolong kurang aktif. Pada siklus I, rata-rata keaktifan belajar siswa adalah 6,27 yang tergolong cukup aktif; sedangkan pada siklus II rata-rata keaktifan belajar siswa adalah 7,57 yang tergolong aktif. Hal itu menunjukkan bahwa terjadi peningkatan keaktifan belajar siswa dari refleksi awal ke siklus I sebesar 1,40, sedangkan dari peningkatan keaktifan belajar siswa dari siklus I ke siklus II sebesar 1,30. Kedua, penerapan pembelajaran kooperatif model STAD dapat meningkatkan hasil belajar IPA siswa kelas VIID SMP Negeri 3 Kubu. Hal itu dapat diketahui melalui hasil evaluasi pada observasi awal, siklus I dan siklus II. Hasil evaluasi pada observasi awal menunjukkan bahwa nilai rata-rata siswa kelas VIID SMP Negeri 3 Kubu sebesar 58,83. Hasil evaluasi pada siklus I menunjukkan bahwa nilai ratarata siswa kelas VIID SMP Negeri 3 Kubu pada pembelajaran IPA adalah 67,67; sedangkan hasil evaluasi pada siklus II menunjukkan bahwa nilai rata-rata siswa kelas VIID SMP Negeri 3 Kubu pada pembelajaran IPA adalah 79,52. Oleh karena itu, terjadi peningkatan sebesar 11,85 dari nilai rata-rata pada siklus I ke siklus II.

Berdasarkan simpulan, beberapa saran yang dapat disampaikan adalah sebagai berikut. Pertama para siswa diharapkan belajar secara optimal dan melibatkan diri secara aktif dalam kegiatan pembelajaran agar hasil pembelajaran pun menjadi memuaskan. Salah satunya melalui belajar bersama kelompok kooperatif. Kedua guru IPA hendaknya tetap mengupayakan penerapan berbagai model pembelajaran yang bervariasi agar kegiatan pembelajaran lebih menyenangkan bagi siswa. Ketiga kepala Sekolah diharapkan mengupayakan pengadaan berbagai sarana yang mendukung efektivitas dan efesiensi kegiatan pembelajaran yang berlangsung di sekolah yang bersangkutan. Keempat peneliti lain diharapkan mengadakan penelitian lanjutan terkait dengan penerapan berbagai model kooperatif yang dapat diterapkan dalam aktivitas pembelajaran pada kelas dan materi yang berbeda dari penelitian yang telah dilakukan ini. Kelima Bagi pengembang Kurikulum, diharapkan penelitian ini dapat dipakai sebagai salah satu dasar pemikiran untuk merumuskan model pembelajaran IPA.

\section{Daftar Rujukan}

Abu Ahmadi. 1984. Strategi Pembelajaran. Bandung: Pustaka Setia.

Agung. 1999. Metodologi Penelitian. Surabaya: Usada Nasional.

Anton, M Mulyono. 2001. Aktivitas Belajar. Bandung: Yrama.

Arikunto. 1996. Prosedur Penelitian. Jakarta: Rineka Cipta.

Asriyah, Nariswati. 2014. Artikel Penggunaan Model Mnemonik Dengan Media Lcd Proyektor Untuk Meningkatkan Keaktifan Dan Hasil Belajar Ips Kelas V Semester Ii Sd Negeri 2 Bandungrejo Kalinyamatan Tahun 2013 - 2014. Guru SD Negeri 2 Bandungrejo Kec.Kalinyamatan Kab. Jepara .

Darma, I Wayan. 2006. "Standar Nasional Pendidikan". Makalah (diseminarkan). Dinas Pendidikan Kabupaten Karangasem. 
Dewi, Kadek Yulli Candra, I Made Suarjana, Ni Wayan Arini. 2016. Penerapan Model Student Fasilitator And Explaining Berbantuan Media Konkret Untuk Meningkatkan Hasil Belajar Matematikasiswa. eJournal PGSD Universitas Pendidikan Ganesha Jurusan PGSD Vol: 4 No: 1.

Depdiknas. 2005. Kamus Besar Bahasa Indonesia. Jakarta: Balai Pustaka.

Dimyati dan Mudjiono. 2006. Belajar dan Pembelajaran. Jakarta. Rineka Cipta.

Djojosuroto, Kinyati dan M.L.A. Sumaryati. 2004. Prinsip-prinsip Dasar Penelitian Bahasa dan Sastra. Bandung: Penerbit Nuansa.

Dwipayana, Ida Bagus Made, I Made Danu Budhiarta, Kadek Yogi Parta Lesmana. 2017. Pengaruh Penerapan Model Pembelajaran Kooperatif Tipe Student Teams Achievement Division Terhadap Hasil Belajar Teknik Dasar Passing Bola Basket. e-Journal PJKR Universitas Pendidikan Ganesha Jurusan Pendidikan Jasmani, Kesehatan, dan Rekreasi Vol 8, No 2,

Hamalik, Oemar. 2001. Proses Belajar Mengajar. Jakarta. Bumi Aksara.

Harmoko 2013. Penerapan pembelajaran kooperatif model student team achievement division (STAD) ditinjau dari keaktifan siswa dan hasil belajar siswa mata pelajaran menggunakan alat ukur kelas $\mathrm{x}$ jurusan teknik pemesinan di SMK muhammadyah prambanan. Tersedia pada https://www.eprints.uny.ac.id/9960/ 1/JURNAL\%20ILMIAH.pdf.diakses pada tanggal 15 Maret 2018.

Ibrahim, dkk. 2000. Pembelajaran Kooperatif. Surabaya: University Press.

Juniati, Ni Wayan dan I Wayan Widiana. 2017. Penerapan Model Pembelajaran Inkuiri Untuk Meningkatkan Hasil Belajar IPA. Jurnal Ilmiah Sekolah Dasar, Universitas Pendidikan Ganesha. Vol.1 (1) pp. 20-29.

Nurkancana dan Sunartana. 1986. Evaluasi Pendidikan. Surabaya: Usaha Nasional

Parmiti, Desak Putu, I Ketut Tunas Arnawa. 2017. Penerapan Metode Inkuiri Berbantuan Media Benda Konkret Dapat Meningkatkan Hasil Belajar Matematika. Journal of Education Action Research Universitas Pendidikan Ganesha Volume 1 No 2.

Permana, Aditya, Susanto dan Arika Indah K. 2014. Penerapan Model Cooperative Learning Tipe Student Teams Achievement Division (Stad) Dalam Meningkatkan Aktivitas Dan Hasil Belajar Siswa Kelas Vii Smp Negeri 2 Suboh Tahun Ajaran 2013/2014. Pancaran, Vol. 3, No. 3, hal 41-52

Sanjaya, Wina. 2006. Strategi Pembelajaran. Jakarta: Media Prenada.

Sardiman. 2007. Interaksi Belajar Mengajar. Jakarta: Raja Grafindo

Sudana, I Putu Ari, I Gede Astra Wesnawa. 2017. Penerapan Model Pembelajaran Kooperatif Tipe Stad Untuk Meningkatkan Hasil Belajar IPA. Jurnal Ilmiah Sekolah Dasar Universitas Pendidikan Ganesha, Volume 1 Nomor 1.

Sulasti, Ni Wayan. 2013. Penerapan Model Pembelajaran Kooperatif Tipe Group Investigation (GI) Untuk Meningkatkan Aktivitas dan Hasil Belajar Siswa Dalam Pelajaran PKn Di Kelas XI IPA 1 SMA Negeri 1 Sawan Tahun Ajaran 2012/2013. Jurusan Pendidikan Pancasila Dan Kewarganegaraan Universitas Pendidikan Ganesha Singaraja.

Susanto, Joko. 2012. Pengembangan Perangkat Pembelajaran Berbasis Lesson Study Dengan Kooperatif Tipe Numbered Heads Together Untuk Meningkatkan Aktivitas Dan Hasil Belajar IPA Di SD. Journal of Primary Educational, JPE 1 (2).

Sunilawati, Ni Made, Nyoman Dantes, I Made Candiasa. 2013. Pengaruh Model Pembelajaran Kooperatif Tipe Stad Terhadap Hasil Belajar Matematika Ditinjau Dari Kemampuan Numerik Siswa Kelas IV 
SD. e-Journal Program Pascasarjana Universitas Pendidikan Ganesha Jurusan Pendidikan Dasar Volume 3

Suyanto, dkk. 1997. Pedoman Pelaksanaan Penelitian Tindakan Kelas (PTK), Pengenalan Penelitian Tindakan Kelas. Yogyakarta: IKIP Yogyakarta.

Tim BSNP. 2006. Panduan Penyusunan Kurikulum Tingkat Satuan Pendidikan Jenjang Pendidikan Dasar dan Menengah. Jakarta: BSNP.

Trianto. 2010. Mendesain Model Pembelajaran Inovatif-Progresif. Jakarta: Kencana.

Trinandita. 1984. Penerapan Metode Pembelajaran Aktif Sebagai Upaya Membantu Meningkatkan Hasil Belajar. http//WWW. Media.diknas.go.id/media/document/5098.pdf.(1 Maret 2013)

Utami, Santi. 2015. Peningkatan Hasil Belajar Melalui Pembelajaran Kooperatif Tipe Stad Pada Pembelajaran Dasar Sinyal Video. Jurnal Pendidikan Teknologi dan Kejuruan, Volume 22, Nomor 4

Wardani, I G.A.K., dkk. 2003. Penelitian Tindakan Kelas. Jakarta: Universitas Terbuka.

Wigih, Riskitri. 2013. Pengaruh Model Pembelajaran Kooperatif TipeStudent Teams Achievement Division (Stad) Terhadap Hasil Belajar Matematika Kelas 5 Sd Negeri Jatiasih X Bekasi. Tersedia pada https://www.repository.uinjkt.ac.id/d space/.../1/RISKITRI\%20WIGIH\%2 0SAYEKTI-FITK.pdf. diakses pada tanggal 13 Maret 2018 